\title{
NOTES
}

\section{PATENT PRICE RESTRICTIONS AND THE ANTITRUST LAWS: A BALANCE UPSET*}

THE legal monopoly created by a patent is in many respects circumscribed by the antitrust laws. ${ }^{1}$ Nevertheless, the Supreme Court early sanctioned in the patent license restrictions which otherwise constituted a per se violation of the Sherman Act. United States v. General Electric expressly recognized that a patentee could establish the price at which a licensee would sell goods he produced under the patent. ${ }^{2}$ Recently, however, the Court, following a general policy of more rigorous application of the antitrust laws, has questioned

* Newburgh Moire Co. v. Superior Moire Co., 237 F.2d 283 (3d Cir. 1956).

1. The patent laws allow a patentee, his heirs and assigns to exclude for a period of seventeen years all others from making, using or vending the patented invention within the United States. 35 U.S.C. $\$ 154$ (1952). The common law grants a patentee the right to practice under the patent himself, except, of course, where such conduct impinges upon another's patent monopoly. Crown Die \& Tool Co. v. Nye Tool \& Mach. Works, 261 U.S. 24, 34-35 (1923) ; Continental Paper Bag Co. v. Eastern Paper Bag Co., 210 U.S. 405, 423-25 (1908) ; Bendix Aviation Corp. v. Kury, 88 F. Supp. 243, 247 (E.D.N.Y. 1950).

All or any portion of such rights may be transferred. Depending upon the quantum of rights conveyed, the transfer may be termed an assignment or license. United States v. General Elec. Co., 272 U.S. 476, 489 (1926).

An assignment results from the sale of all rights in the patent. Since the right of assignment stems from the patent statute, it is governed by federal law. 35 U.S.C. $\$ 261$ (1952); Jewett v. Atwood Suspender Co., 100 Fed. 647 (C.C. Vt. 1900). A license, merely a transfer of a limited right to practice the patented disclosure, falls within state control. L. L. Brown Paper Co. v. Hydroiloid, 32 F. Supp. 857, S67 (S.D.N.Y. 1939), aff'd, 118 F.2d 674 (2d Cir.), cert. denied, 314 U.S. 653 (1941); Farmland Irrigation Co. v. Dopplmaier, 48 Cal. 2d 208, 308 P.2d 732 (1957). For a general discussion of the distinctions between licensing and assignment, see Toulmin, HandBoor of Patents 42535 (2d ed. 1954) (hereinafter cited as TouLMIN). See also United States v. General Elec. Co., supra; Waterman v. MacKenzie, 138 U.S. 252 (1891); Kenyon v. Automatic Instrument Co., 160 F.2d 878 (6th Cir. 1947).

2. United States v. General Elec. Co., supra note 1. A license under a patent protecting tungsten light bulb filaments was issued to Westinghouse by General Electric. General Electric produced $61 \%$ of the incandescent lamps on the market, and Westinghouse 16\%. United States v. General Elec. Co., 15 F.2d 715, 716 (N.D. Ohio 1925). Westinghouse was required to follow prices and terms established by General Electric. The price-fixing term was upheld, as was a system of distribution allegedly designed to maintain resale prices.

Absent patent protection, such price fixing would constitute a per se violation of $\$ 1$ of the Sherman Act. United States v. Trenton Potteries Co., 273 U.S. 392 (1927); American Column \& Lumber Co. v. United States, 257 U.S. 377 (1921). See also Report of thE Atrorney General's National Committee To Study the Antixrust Laws 12-24 (1955) (hereinafter cited as ATtY GEN. REP.). To fall within the aegis of the patent law, the patent supporting the price-fixing license must be "primary" and cover the entire product. Thus, General Electric was not allowed to continue its former licensing practice through 
the advisability of such price-fixing agreements. ${ }^{3}$ In a series of decisions, it has invalidated a number of pricing licenses primarily on the ground that the agreements resulted from an active conspiracy among the members of an industry to establish price regimentation. ${ }^{4}$ But language in certain of these

using subsidiary patents after the primary patent had expired. United States v. General Elec. Co., 82 F. Supp. 753, 815 (D.N.J. 1949).

Generally, a licensee is estopped from challenging the validity of a patent under which he is licensed. Similar rules hold for assignments. Automatic Radio Mfg. Co. v. Hazeltine Research, Inc., 339 U.S. \$27, 836 (1950) ; Westinghouse Elec. \& Mfg. Co. v. Formica Insulation Co., 266 U.S. 342, 349 (1924) ; Hall Laboratories, Inc. v. National Aluminate Corp., 224 F.2d 303, 306-07 (3d Cir. 1955). In a suit against his licensor, the licensee may attack the patent only on such subsidiary issues as the scope and duration of the patent. Scott Paper Co. v. Marcalus Mfg. Co., 326 U.S. 249 (1945) (patent expired) ; Westinghouse Elec. \& Mffg. Co. v. Formica Insulation Co., supra at 351 (scope of patent); Casco Product Corp. v. Sinko Tool \& Mfg. Co., 116 F.2d 119 (7th Cir. 1940) (same). However, the Supreme Court, moved by the inherent illegality of price agreements generally, has permitted the licensees to contest the validity of patents when the license contains price-fixing provisions. Sola Elec. Co. v. Jefferson Elec. Co., 317 U.S. 173 (1942) (suit for failure to follow prices); MacGregor v. Westinghouse Elec. Co., 329 U.S. 402 (1947) (contest countenanced despite promise not to challenge); Edward Katzinger Co. v. Chicago Metallic Mfg. Co., 329 U.S. 394 (1947) (licensee, seeking declaratory judgment, had requested the price fixing).

The protection granted by the patent is limited. A single sale is said to exhaust the patent and invalidate attempts to set maximum or minimum resale prices by license. Ethyl Gasoline Corp. v. United States, 309 U.S. 436 (1940); Bloomer v. Millinger, 68 U.S. (1 Wall.) 340 (1863). But see F. C. Russell Co. v. Consumers Insulation Co., 119 F. Supp. 119, 122 (D.N.J. 1954) (maximum resale price upheld).

Moreover, a process patent, covering a series of steps or procedure to secure a given result, TouLMIN 38, does not empower the patentee to establish the sale price of the resulting praduct, Cummer-Graham Co. v. Straight Side Basket Corp., 142 F.2d 646 (5th Cir. 1944) ; Barber-Colman Co. v. National Tool Co., 136 F.2d 339 (6th Cir. 1943) ; American Equipment Co. v. Tuthill Bldg. Material Co., 69 F.2d 406 (7th Cir. 1934) ; United States v. General Elec. Co., 82 F. Supp. 753, 814 (D.N.J. 1949). Contra, Straight Side Basket Corp. v. Webster Basket Co., 82 F.2d 245 (2d Cir. 1936).

3. See Rostow, The New Sherman Act: A Positive Instrument of Progress, 14 U. Chr. L. Rev. 567 (1947) ; Sunderland, Changing Legal Concepts in the Antitrust Field, 3 SyRacuse L. Rev. 60, 67-68 (1951).

A "formula" for distinguishing legitimate patent practices from antitrust violations ostensibly originated in United States v. General Elec. Co., 272 U.S. 476 (1926). The patentee may grant a license to make, use and vend articles defined by the specifications of the patent upon any condition reasonably within the reward which the patentee is entitled to secure from the patent grant. $I d$. at 489 . Although widely quoted, the "formula" can be of little help. See, e.g., General Talking Pictures Corp. v. Western Elec. Co., 305 U.S. 124 (1938). The problem is defining just what "conditions" are within the patent grant, and this definition can only be achieved through a case by case process evaluating the effects of a particular license practice in light of patent and antitrust policies. See Mercoid Corp. v. Mid-Continent Inv. Co., 320 U.S. 661, 665-66 (1944).

4. United States v. New Wrinkle, Inc., 342 U.S. 371 (1952); United States v. United States Gypsum Co., 333 U.S. 364 (1948); United States v. Line Material Co., 333 U.S. 287 (1948); United States v. United States Gypsum Co., 340 U.S. 76 (1950). See also United States v. Masonite Corp., 316 U.S. 265 (1942).

The first Gypsum case came to the Supreme Court from a district court dismissal of a government complaint alleging conspiracy in violation of $\S 1$ of the Sherman Act. United 
cases was broader and led lower judicial tribunals as well as commentators to doubt the patentee's right to price-fix in any context. ${ }^{5}$

States v. United States Gypsum Co., 53 F. Supp. 889 (D.D.C. 1943). Evidence had been introduced tending to prove that Gypsum, after extensive multilateral negotiations, had issued patent licenses containing price restrictions to essentially all the manufacturers of gypsum plasterboard, lath and wallboard sold east of the Rockies. The agreement comprehensively governed all phases of the manufacture, distribution and sale of these products, whether protected by the patents or not. Unanimousiy reversing and remanding for trial, the Court found that United States v. General Elec. Co., 272 U.S. 476 (1926), "gives no support for a patentee, acting in concert with all members of an industry, to issue substantially identical licenses to all members of the industry under the terms of which the industry is completely regimented, the production of competitive unpatented products suppressed, a class of distributors squeezed out, and prices on unpatented products stabilized." United States v. United States Gypsum Co., 333 U.S. 364, 400 (1948). The precise holding was that even if each patent license issued was legal, a $\$ 1$ offense would follow from a showing that the defendants-constituting all former competitors in an industry-had acted in concert to use patent licenses for organizing the industry and stabilizing prices. Id. at 401 . Proof of collusion would result from a finding that each of the alleged conspirators signed identical licenses with knowledge that all other parties had assumed like responsibilities. The sufficiency of such evidence was first articulated in Interstate Circuit, Inc. v. United States, 306 U.S. 208, 226 (1939), and reaffirmed in United States v. Masonite Corp., supra at 275.

Factually, United States v. New Wrinkle, Inc., supra, closely paralleled the first Gypsum case. As a result of multilateral infringement litigation, the parties agreed to assign the primary patents in question to New Wrinkle, a corporation formed expressly to hold, and license under, the patents. The price provisions were not to operate until twelve specified manufacturers joined the arrangement. Ultimately, New Wrinkle licensed over 200 manufacturers, substantially the entire industry. The licensing system rigidly controlled the price and terms of sale of the products with an elaborate system of "bulletiss." Relying on the first Gypsum case, and United States v. Line Material Co., supra, the Court deemed the practices a Sherman Act violation. United States v. New Wrinkle, Inc., supra at 380 .

In Line Material, two small fuse manufacturers holding interdependent patents crosslicensed each other, with the stipulation that one would establish the sale price of products manufactured under the patent by either and by any other producer taking a license under the patents. No conspiracy to price-fix the industry was alleged, but the Court found price fixing by two competitors under a cross-licensing arrangement illegal in itself. United States v. Line Material Co., supra at 314-15; see note 5 infra.

5. See United States v. Line Material Co., supra note 4, at 315. Farley, Price Firting and Royalty Provisions in Patent Licenses, 34 J. PAT. OFF. Soc'Y 46 (1952); Note, 61 Harv. L. Rev. 1427 (1948); Note, 43 Ill. L. Rev. 400 (1948). Contra, Rogers, Price Contral Under Patent Agreements, 12 U. PiTT. L. Rev. 569, 586 (1951).

Concurring in Line Material, Mr. Justice Douglas, writing for himself and three other Justices, would have overruled United States v. General Elec. Co., 272 U.S. 476 (1926). Mr. Justice Reed, writing for the Court, and the three dissenting Justices considered the case good law. Thus, General Electric was affirmed by an equally divided Court. Mr. Justice Reed sought to distinguish the factual circumstances of Line Material from those of General Electric and rested the decision of the Court on the illegality of price fixing pursuant to a cross-licensing agreement. The concurring Justices found nothing more onerous in such a practice than in price fixing under a single patent and were unable to distinguish the two situations.

Mutually blocking patents have been considered essentially equivalent to a single usable patent. So viewed, agreement of the patentees should not of itself constitute a 
This revised attitude is illustrated by the holding of the Third Circuit in Nowburgh Moire Co. v. Supcrior Moire Co. ${ }^{6}$ The action originated in a suit by Newburgh for infringement of its process patent. ${ }^{7}$ Counterclaiming, Superior charged plaintiff with violation of the antitrust laws by reason of price restrictions placed in licenses issued under the patent. ${ }^{8}$ Although only two members of a five-company industry did not practice under the patent, neither conspiracy nor intent to regiment the industry was alleged.9 And while the court found no conspiracy to exist, it nevertheless held the price-fixing agreement illegal. The later Supreme Court decisions were interpreted to allow price-fixing terms in one but not a number of patent licenses. ${ }^{10}$

conspiracy. Thomas, The Patentee's Dilemna-Is Price Fixing Legal?, 4 Mranr L.Q. 313, 323-30 (1950). See also Kligler, Recent Indicial Limitation of the Patent License Contract, 30 J. PAT. OFF. Soc'y 685, 687 (1948).

6. 237 F.2d 283 (3d Cir. 1956).

7. Newburgh Moire Co. v. Superior Moire Co., 105 F. Supp. 372 (D.N.J. 1952). The process patent covered a method of finishing textiles. Id. at 373-74.

Intermediate rounds of this complicated affair were fought at 116 F. Supp. 759 (D.N.J. 1953) ; 218 F.2d 580 (3d Cir. 1955) ; 136 F. Supp. 923 (D.N.J. 1955). For further discussion of this litigation, see 55 Mrce. L. REv. 726 . (1957) ; 105 U. PA. L. Rev. 411 (1957) ; 43 VA. L. REv. 101 (1957).

8. Newburgh Moire Co. v. Superior Moire Co., 105 F. Supp. 372, 376 (D.N.J. 1952). The licenses in question only established the minimum price to be charged for the patented process. Id. at 374. No attempt was made to price-fix the goods produced by the patent, as such conduct had long been held illegal. See note 2 supra.

Equity courts have traditionally withheld their aid if a plaintiff is attempting to pursue his rights contrary to the public interest. Virginian Ry. v. System Federation 40, Railway Employees, AFL, 300 U.S. 515, 552 (1937) ; Pennsylvania v. Williams, 294 U.S. 176, 185 (1935) ; Beasley v. Texas \& Pac. Ry., 191 U.S. 492, 497 (1903) ; De Funiak, Handbook of MOUERN EQUiT 40-41 (2d ed. 1956). Thus, a patentee who "misuses" his patent by attempting to expand his monopoly beyond its permissible scope has been unable to obtain what would otherwise constitute justifiable relief for infringement-an injunction and an accountiug. Mercoid Corp. v. Mid-Continent Inv. Co., 320 U.S. 661 (1944) ; Morton Salt Co. v. G. S. Suppiger Co., 31+ U.S. 488 (1942). And use of a patent in violation of the antitrust laws constitutes patent misuse, with all of the resultant consequences to the patentee. HartfordEmpire Co. v. United States, 323 U.S. 386,415 (1945) ; Kobe, Inc. v. Dempsey Pump Co., 198 F.2d 416 (10th Cir.), eert. denied, 344 U.S. 837 (1952). Of course, violation of the antitrust laws may also be sufficient ground for a separate suit for treble damages. 26 Sтат. 210 (1890), 15 U.S.C. $\$ 15$ (1952); Kobe, Inc. v. Dempsey Pump Co., supra; Hughes Toul Co. v. Ford, 114 F. Supp. 525 (E.D. Okla. 1953), modified, 215 F.2d 924 (10th Cir. 1954). Moreover, use of the patent monopoly in contravention of the antitrust laws may lead to such drastic penalties as compulsory licensing and divestiture of patents. United States v. National Lead Co., 332 U.S. 319 (1947): United States v. United Shoe Mach. Corp., 110 F. Supp. 295 (D. Mass. 1953) : United States v. IB.M, 1956 Trade Cas. II 68245 .

9. Newburgh Moire Co. v. Superior Moire Co., 105 F. Supp. 372, 374 (D.N.J. 1952). 10. 237 F.2d at 292-94.

In Nezeburgh, the court found difficulty in distinguishing New Wrinkle from General lilectric. See note 4 supra. Although the firms in Nea Wrinkle constituted $90 \%$ of the relevant market, the court felt that illegal co-operation was less likely than in General Electric, where only $76 \%$ of the market was controlled. For 200 firms were represented in the New Wrinkle conspiracy. And the court argued that the licenses would be far more 
This single-licensee interpretation appears technically unwarranted. The court construed an offhand statement by Mr. Justice Reed in United States $v$. Line Material Co.- the case generally recognized as most severely questioning the right of patent price fixing-that a patentee might legally license "another" with price restrictions to mean that a patentee might impose such conditions in "only one" license. ${ }^{11}$ But use of the singular "another" does not negate a broader construction than that assumed by the court; the terms "another" and "others" are often used interchangeably. ${ }^{12}$ And the context within which the statement was made would appear to render the court's interpretation meaningless. In the sentence immediately preceding the statement relied upon by the court, Mr. Justice Reed expressly disclaimed any attempt at establishing the scope of permissible price-fixing arrangements. ${ }^{13}$ Moreover, in deciding a case subsequent to Line Material, the Supreme Court through Mr. Justice Reed explicitly reserved as undecided any question relative to the legality of a number of patent licenses containing price restrictions. ${ }^{14}$

A criterion of legality directed only to the number of licensees seems indefensible except as a convenient judicial means of limiting patent price fixing.

difficult to police than those involved in General Electric, where only two firms co-operated. However, since General Electric controlled $61 \%$ of bulb manufacture itself, vigorous competition in that industry was unlikely in any event. Edwards, Marntaining CompeTITION 91, 101, 105, 153-55 (1949). In the New Wrinkle industry, on the other hand, price fixing jeopardized the competition usually attending the existence of numerous firms.

11. 333 U.S. 287, 304 (1948) : "In these circumstances [lack of a majority to affirm or overrule], we must proceed to determine the issues on the assumption that General Electric continues as precedent. ... On that assumption where a conspiracy to restrain trade or an effort to monopolize is not involved, a patentee may license another to make and vend the patented device with a provision that the licensee's sale price shall be fixed by the patentee." The Newburgh court, in interpreting this statement to enunciate a singlelicensee doctrine, may have been influenced by the dictum of Mr. Justice Douglas in United States v. Paramount Pictures, Inc., 334 U.S. 131 (1948). Although that case involved copyright licenses only, Mr. Justice Douglas, in analogizing to the patent law, seemed to imply that Line Material had limited General Electric strictly to its facts-only one license with price limitations could be issued. Id. at 144. For comment on this position, see Rogers, supra note 5 , at 577.

12. State ex rel. Crown Coach Co. v. Public Serv. Comm'n, 238 Mo. App. 287, 297-99, 179 S.W.2d 123, 127 (1944) ; Eastham v. Holt, 43 W. Va. 599, 604, 27 S.E. 883, 884 (1897); see 105 U. PA. L. Rev. 411, 413 (1957).

13. "Furthermore we do not think it wise to undertake to explain, further than the facts of this case require, our views as to the applicability of patent price limitation in the various situations listed by the government." 333 U.S. at 304 . The government questioned, inter alia, whether intermediate patents could support price fixing of the final good, the extent to which the patent must dominate the price-fixed article to allow price fixing, the legality of price fixing with pooled patents and the marketing restrictions which could be placed upon licensees. Brief for Appellants, pp. 65-68.

14. "It was not necessary to reach the issue as to whether a mere plurality of licenses, each containing a price fixing provision, violates the Sherman Act." United States v. United States Gypsum Co., 340 U.S. 76, 85 (1950). This second Gypsum case was an appeal from the final decision of the district court after trial on remand. See note 4 supra. 
Unquestionably, price-fixing agreements effected through an industry-wide conspiracy cannot be sustained. Their objective is not exploitation of the patented product but utilization of the protected monopoly to shield objectionable conduct. ${ }^{15}$ The single-licensee doctrine, on the other hand, does not possess any comparable logic. No consideration is given to the fraction of the industry controlled by the patentee and licensee and thus to the effect which such an agreement may have upon prices. ${ }^{16}$ Justified as denying licensees rewards which generally may be obtained only through horizontal co-operation, the single-licensee doctrine provides a lone licensee with just such benefits. ${ }^{17}$

15. "The rewards which flow to the patentee and his licensees from the suppression of the competition through the regulation of an industry are not reasonably and normally adapted to secure pecuniary reward for the patentee's monopoly." United States v. United States Gypsum Co., 333 U.S. 364, 401 (1948).

If the members of an industry wish to eliminate price competition, they may all take price licenses under a patent and at the same time not produce competitive goods. Competition from equivalent goods thus eliminated, price competition is avoided since the only product sold is price-fixed. Moreover, such agreements would tend to reduce incentive to invent new competing products or processes. And the patent used to promote the scheme may even be of questionable validity. See, e.g., United States v. Masonite Corp., 316 U.S. 265, 278-79 (1942) (del credere agency device to regulate prices and suppress competition). See also Steffen, Invalid Patents and Price Control, 56 Y ALE I.J. 1-6 (1946) ; Diggins, The Patent-Antitrust Problem, 53 Mrcr. L. Rev. 1093-95 (1955).

16. See 105 U. PA. L. REv. 411, 414 (1957). Under the single-licensee doctrine, the test of illegality is based solely upon the number of licensees which practice the patent under price limitations. Illegality follows whether the multiple licensees, plus the patentee if he practices the patent, control an insignificant percentage of the relevant market or dominate it. As a result, price fixing in patents, which traditionally has been more liberally treated than price fixing in the more general economic context, may become more restricted. While price fixing is generally thought to be per se illegal, only where defendant's acts significantly affect the market as a whole will the conduct be held in violation of the antitrust laws. See Appalachian Coals, Inc. v. United States, 288 U.S. 344 (1933) ; Board of Trade v. United States, 246 U.S. 231, 240 (1918). But, of course, the singlelicensee doctrine might be interpreted not to embrace patent pricing agreements with little or no market effect.

17. Licensing provisions which appear principally designed to benefit the licensee are judicially disfavored and are usually not granted exemption from the antitrust laws. United States v. Paramount Pictures, Inc., 334 U.S. 131, 144 (1948); Interstate Circuit, Inc. v. United States, 306 U.S. 208, 230 (1939) ; United States v. Krasnov, 143 F. Supp. 184 (E.D. Pa. 1956) (price fixing); United States v. Crown Zellerbach Corp., 141 F. Supp. 118, 127 (N.D. Ill. 1956) (territorial restrictions); United States v. Besser Mfg. Co., 96 F. Supp. 304, 311 (E.D. Mich. 1951), aff'd, 343 U.S. 444 (1952) (veto power over new licensees); United States v. Vehicular Parking Ltd., 54 F. Supp. 828, 838 (D. Del. 1944) (price fixing by nonproducing licensor). See also Rogers, supra note 5, at 586.

Any benefits which would inure to multiple licensees would accrue equally to the one licensee under the single-licensee doctrine. For to him, the producing patentee is just another competitor. And the elimination of price competition between these two parties resuits in benefits similar to those resulting from price agreement with any competitor or competitors. If the patentee does not produce himself, the lone licensee does not, of course, confront the prospect of competition; he is a monopolist. Arguably, however, some or all of the excess profits which licensees might obtain through reduced competition 
Even were the doctrine effective in this regard, patent policy should seek a balance between benefit to the patentee and harm to the public rather than focus on incidental reward accruing to third parties. ${ }^{18}$

Furthermore, any policy directed to the evils underlying licensing price fixing-restriction of licensee competition in patented goods-cannot be fully implemented by invalidating price-licensing agreements. Territorial limitations are expressly authorized by the patent statute. ${ }^{19}$ To the extent such factors as high transportation costs insulate individual territories from one another and preclude resale of goods among them, these limitations may be as effective as price fixing. With only a single seller in each area assigned, no competition between licensees could occur. And if different territories manifest different demands, the patentee's profits--percentage royalties-could be further enhanced since his licensees would be able to charge differing prices in each territory." Even absent such optimum conditions, the patentee could achieve price-fixing results by imposing quantity controls. ${ }^{21}$ Through their effect on supply; these

among each other could be extracted by the patentee in the form of increased royalties. To the extent profits are in fact extracted, the restrictions may be viewed as benefiting the patentee rather than the licensee.

Attempts by patentees to set the resale price of products manufactured by licensees under the patent present a similar situation and are universally held illegal. Ethyl Gasoline Corp. v. United States, 309 U.S. 436, 452-53 (1940); Bauer \& Cie v. O'Donnell, 229 U.S. 1 (1913).

18. Wron, Patents and Airtitrust Law 21 (1942). See also note 3 stpra; note 36 infra. Hollabaugh, Patents and Antitrust Laws, 25 U. Cin. L. REv. 43, $45-46$ (1956).

19. 35 U.S.C. $\$ 261$ (1952): "The applicant, patentee, or his assigns or legal representatives may in like manner grant and convey an exclusive right under his application for patent, or patents, to the whole or any specified part of the United States." This grant has been construed as permitting territorial restrictions in patent licenses. Brownell v. Ketcham Wire \& Mfg. Co., 211 F.2d 121 (9th Cir. 1954). A patentee may similarly preclude his licensee from the export market. Ibid. But patents may not be used as the basis of international market-sharing agreements. United States v. General Elec. Co., 82 F. Supp. 753, 827-48 (D.N.J. 1949) ; cf. Timken Roller Bearing Co. v. United States, 341 U.S. 593 (1951) (attempted use of trademark to allocate international market).

20. A producer will maximize profits by setting price or output at that level where the extra income derived from the last sale is equal to the cost of producing that last unit. The extra income and cost of the last units are termed marginal revenue and marginal cost, respectively. Marginal cost usually varies with output, reflecting the different per unit costs of producing at each separate level of output. Marginal revenue is constant only in pure competition, and then it is always equal to price. In other market structures (monopoly, oligopoly, monopolistic competition), marginal revenue decreases with increasing sales and is below price. SAMUELSON, Economics 447-50 (3d ed. 1955).

If demand conditions differ in two markets, the producer is faced with two different demand curves, and he will maximize profit by setting separate prices so that marginal cost is equal to marginal revenue in each market. In essence, he charges consumers with intensive demand for the product more than buyers with weaker desires for the good. This practice will only be feasible if the weak demand group cannot resell to those with the stronger demand, who are paying higher prices. Boulding, Econonic Analysis 609-15 (3d ed. 1955).

21. Although no direct ruling has been made, quantity limitations in patent licenses have been endorsed by dicta. Extractol Process, Itd. v. Hiram Walker \& Sons, Inc., 153 F.2d 
controls are virtually identical to price restrictions. ${ }^{22}$ Not protected by statute, they would have to fall with price licensing.

Denial of power over price or quantity would, however, exaggerate the disadvantage of those patentees who are incapable of producing the optimum volume of the patented product. An owner developing his patent entirely by self-production could realize full monopoly profits. ${ }^{23}$ In contrast, the patentee required to commereialize by licensing others to manufacture and sell the patented good would not obtain full monopoly return. ${ }^{24}$ With incomplete control over total production and with numerous licensees each seeking to maximize his own profits, the optimum price and output level of the industry as a whole, and thus of the patentee himself, may never be achieved. ${ }^{25}$ This

264, 266 (7th Cir. 1946) ; American Equipment Co. v. Tuthill Bldg. Material Co., 69 F.2d 406, 40S (7th Cir. 1934); ATr'y GEN. REP. 236. The scarcity of cases suggests that this method of price control is unpopular with patentees and licensees. Possibly, licensees feel that quantity controls are overly restrictive since they render nonprice competitive methods, such as advertising and service, useless to achieve a greater share of the market than that originally contemplated. See Chamberlin, Theory of Monopolistic CompetiTION 71-72 (7th ed. 1956).

22. The output of any product and the price that output will command are interrelated. Setting either variable will determine the other; thus control over volume will enable price fixing. Sanuelson, Economics 367-68 (3d ed. 1955).

Morcover, quantity controls may be easier to police than price restrictions and hence be more efficient. Most price-control systems run the risk of partial subversion by secret rebates, overly generous quantity discounts or superior credit terms. These are difficult to curb without elaborate detection systems. For examples of systems devised to prevent price cutting, see United States v. New Wrinkle, Inc., 342 U.S. 371, 375 \& n.4 (1952); Sugar Institute, Inc. v. United States, 297 U.S. 553, 579-83 (1936) ; FTC v. Beech-Nut Packing Co., 257 U.S. 441, 447-51 (1922). However, quantity restrictions, especially if combined with per unit royalty payments, would be far simpler to police. Under per unit royalty agreements, the patentee is generally permitted access to the licensee's production records to compute the royalty due. Any attempt at concealing evidence of the volume actually produced would not only be difficult, but would entail fraud since the patentee would be deprived of his rightful royalty payments. See St. CLaIR, Drafting ROYALTY-BEARING LICENSES 15 (1951).

23. A patentee producing alone naturally has full power over the price or, identically, the output of his product. See note 25 infra.

24. By licensing, the patentee creates new centels of output and price decision and no longer has unilateral control of the market. Some power is retained by his ability to affect the licensee's costs through royalty charges. See ATT'y GEN. REP. 235-36 (dissent of Louis B. Schwartz); Fariey, supra note 5, at 58. See also note 25 infra.

25. Optimum production level refers to the output which, if produced at the highest possible efficiency, will yield the greatest profits. See Boulding, Economic Analysis 563-73 (3d ed. 1955). If the patentee boasts this capacity and efficiency, he can himself produce the requisite output. If not, he must divide production with licensees if he wishes the optimum output level to be reached. Ibid.; cf. Patinkin, Firms, Cartels and Imperfect Competition, 61 Q.J. Ecos. 173, 174-85 (1947). However, as soon as independent sources of decision in the form of licensees are created, problems of inducing the optimum price and production level arise. See note 34 infra.

The possession of a final-consumer-good patent confers some quantum of monopoly power by the patentee's freedom to adjust price without losing all his customers. The extent of his price range in turn depends upon how willing consumers are to substitute 
disability of the nonproducing patentee is compounded by an impaired bargaining position; unable to exploit his monopoly individually, he may have difficulty in inducing potential licensees to meet his demands for full monopoly royalties. ${ }^{26}$

other goods for his product when faced with price increases. See ST. CLAIR, op. cit. supra note 22 , at 11 . These considerations apply to any monopoly. Bowman \& BACH, Economic Analysis and Public Policy 160-63, 283-86 (1946); EnkE, Intermediate EConomic Theory 295-96 (1950). Thus, the final-good patentee must behave like a monopolist to capitalize his invention, and price and output must be set so that marginal revenue equals marginal cost. Bain, Pricing, Distribution, and Employarent 140-47 (1948).

If the patentee is the only producer, he will, of course, himself set the optimum price. If the patentee licenses, the optimum price and total output will be similarly computed so that total industry monopoly profits can be maximized. The proportion of total monopoly profits obtained by the patentee depends upon the extent to which he is successful in extracting, by royalties, those excess profits attributable to the patent. See Pererson, EcoNomics 522-24 (1949). The exact amount depends upon factors discussed in note 26 infra.

The patentee's problem is how to induce each licensee to produce at the output at which total industry production and price will be at the maximizing point. If the licensees are sufficiently numerous to act like competitors, the patentee can induce the optimum price and output by manipulating royalty charges. Generally, in the competitive case, both the individual producer's and the industry's price and output can be determined if the total demand and the individual cost curves of the members are known. Marginal revenue is seen as equal to price, and each licensee assumes his output will have no effect on the final price. Thus, he merely adjusts output so that marginal cost equals marginal revenue. C patentee, however, has control over each licensee's marginal costs through his ability to vary royalty charges. If he knows each licensee's other costs and chooses the proper number of licensees, he can set the royalty so that the industry price will be optimum and each licensee will produce just that output which makes total production optimum. In effect, the patentee influences the licensee's marginal cost curve to intersect his marginal revenue curve at the desired point. See Samuelson, Economics 447-50 (3d ed. 1955).

However, if there is more than one producer, but less than enough to create "pure" or "perfect" competition, each licensee knows his production affects price but cannot be sure of his rival's reactions to any of his moves. The predicted price and output depend upon assumptions concerning each seller's view of his direct and indirect effect on the market, whether sellers change price or output, and the uncertainty of each seller about his competitors' plans. As a result, the price to be achieved can at no time be specified with certainty and might be monopoly price, competitive price, a price intermediate between the two or even an oscillating price. ChamberLin, op. cit. supra note 21, at 30-55. See also Fellner, Comipetition Among the Few 25-41, $93-97$ (1949). In such a situation, the patentee does not know each licensee's demand curve and thus cannot ascertain the effect of setting various royalties. Therefore, he cannot induce each licensee to produce at the price and output he wishes, and optimum price and output may not be reached.

But if the patentee has control over the price or production level of his licensees, the fact that he does not know their individual demand curves is of no moment. All he must know is the industry demand and individual cost curves, the same data he would need if attempting to maximize solely by manipulating royalties. He will then allocate production over his licensees so that optimum output will be reached and industry profits maximized. The patentee has the opportunity of extracting all the monopoly profits through royalties. See Patinkin, supra at 174-85.

26. Ability to self-produce is one of many factors which make up bargaining strength. See St. ClaIR, op. cit. supra note 22, at 11-18 (exhaustive discussion of the formulation 
Moreover, if quantity and price-licensing privileges were eliminated, the owner of an intermediate patent would enjoy a better position than the final patentee. Broadly classified, patents fall into two general categories. A final patent protects products which themselves satisfy consumer demand. ${ }^{27}$ An intermediate patent may be defined as encompassing products and processes which directly or indirectly contribute to the formation of a final good; intermediate patents are useful only in so far as the patented product or process performs more efficiently the role of an existing good. ${ }^{28}$ While full exploitation of a final patent requires complete control of the product's price or quantitymonopoly reward is gained when price and total volume are at that level where marginal cost equals marginal revenue $-{ }^{29}$ such dominion is not always essential in an intermediate patent..$^{30}$ Volume is necessarily limited by the demand for the final product. ${ }^{31}$ And the ideal price of the intermediate patent is generally

of royalties). Other factors include the relative resources of the parties, the alternatives open to them, the number of potential licensees, knowledge of the markets and the skill of each individual as a bargainer. Cf. Dunlop, Wage Defremination Under Trade Unrows 74-78, 91-92 (1944); Slichter, The Determinants of Bargaining Power, in CoLlective Bargaining Contracts 46-48 (1941).

27. The final patent has been defined to encompass new consumption goods which are purchased to satisfy consumer wants. Examples include home furnishings, clothing, food and entertainment. Boulding, Economic Analysis 680-81 (3d ed. 1955).

28. Intermediate patents are of two general types. One includes goods or processes which are not produced for their own sake, but help further production of a final consumption good as defined in note 27 supra. Examples include cloth, steel ingots, tool dies and material moving machinery. The other embraces new ways of producing an existing final good. Glass blowing devices and the finishing process involved in the Newburgh case are examples of this rather narrow category. Classification of some goods, and thus the patent on them, depends on the specific use to which they are put. Thus, automobiles used by consumers would be final goods, but the same automobile employed as part of a business would be an intermediate good. See SAMuEIson, Economrcs 190 (3d ed. 1955).

Intermediate patents fulfill a commercial need only if the existing service is impractical because of a scarcity of resources, unobtainable because of limitations through patents or otherwise less efficient. See, e.g., Hartford-Empire Co. v. United States, 323 U.S. 386, 392-401 (1945) ; Standard Oil Co. v. United States, 283 U.S. 163 (1931). Such patents, even though not significantly more efficient than an existing good or process, may be a convenient vehicle for price regimentation of an industry. See note 15 supra. Such use of a patent is, of course, illegal.

29. See note 25 supra.

30. Intermediate patents are valuable because of the cost savings their use entails. The patentee will allow others to use his product, and thus effect savings, only if part of these savings are paid to him in royalties. The upper limit to royalty payments is the total savings the patent permits over the best available substitute. ST. CIAIR, op. cit. supra note 22, at 11-12. The exact royalty will depend on the parties' relative bargaining strengths. See note 26 supra.

31. Ultimately, all demand stems from the consumer. The direct effect of consumer demand on final goods moves suppliers to purchase those intermediate factors necessary to produce them. Thus, the demand for intermediate products will usually remain unchanged so long as demand for the relevant final good is constant. As a result, a producer who furnishes the entire supply of an intermediate good would have no reason to cut price, since he could not increase sales at the lower price. Similarly, the owner of an 
that which will just persuade purchasers to replace the existing service with the patented innovation. ${ }^{32}$ Thus, licensees are less likely to engage in price competition for the fixed market protected by the intermediate patent than they are in the final market where demand is not predetermined. ${ }^{33}$ The intermediate patentee accordingly tends to suffer less from denial of price or quantity controls than does the owner of a final patent. ${ }^{34}$

intermediate patent has no reason to set the price of his patented service lower than that necessary to induce customers to stop using the old good and switch to his newer, cheaper substitute. Actually, the market for intermediate products operates similarly to that of labor, since both are necessary to the production of any final good. Bownins \& BACH, op. cit. supra note 25, at 239-43; Boulding, Economic Analysis 204-07 (3d ed. 1955). If an intermediate good represents a large part of the total cost of the final product, and if the industry is highly competitive, with free entry and flexible prices, a reduction in the price of the intermediate good may so lower the price of the final good as to lead to an increase in its demand, and thus the demand for the intermediate patent. In that case, it could be beneficial for the intermediate patentee to set his price below that previously prevailing if demand for the final good is elastic and if a reduction in price will create enough new demand to increase total profits. Ibid.

32. See note 31 supra.

33. Generally, the smaller the patent profits bargained for by the licensee, the more likely will price competition be to reduce price below licensee cost and the more unlikely will the prospect of price competition become. See Edwards, Manintaining Comipetimon 101 (1949) ; 105 U. PA. L. REv. 411, 414 (1957) ; notes 25, 26, 30 supra. The relative efficiencies of the parties producing the patent may also affect the possibility of price competition. If one party is more efficient than the others, the likelihood of price competition is enhanced, since such producer has a lower cost and a larger margin of profit in which to function before price becomes less than cost. ATT'Y GEN. Rep. 235-36 (dissent of Louis B. Schwartz). On price competition generally, see Backnan, Price Practices and Price Policies 119-48, 378-417 (1933) ; Machlup, Econonics of Sellers' Competition (1952).

34. The patentee may obtain return both from royalties charged licensees and selfproduction. Although total demand for the patented intermediate product may be fixed, each licensee might be tempted to cut price to obtain some of the market of his competitors, both the patentee and other licensees. See note 31 supra. In the event of price cutting, the exact effect upon a self-producing patentee's profits will depend upon the royalty he extracts from licensees and the ease with which he can abandon production. If the royalty is a fixed percentage of selling price, price competition will reduce patentee profits accordingly. Moreover, if the patentee is himself practicing the patented disclosure, any price cut will impinge upon the entrepreneurial and patent profits obtained from his own sales. Since the demand for an intermediate good is largely insensitive to price, the cut will not proportionately increase sales, and thus profits. And, since all competitors will generally meet the price cut, no individual increase in production is likely to accompany the decreased price.

If the royalty is substantially equal to the full monopoly value of the patent and not dependent upon price, and if the patentee can easily reduce or stop production, he would be best off halting production and allowing his licensees to take over his share of the market. During price competition, on every sale he himself makes he loses the difference between optimum price and actual sale price. If the same good were sold by a licensee, no such loss would result, since the royalty is independent of price. However, if royalties are low compared with the value of the patent, and the patentee obtains proportionately more from his own use or sales than from licensee royalties, he cannot afford to lose any business; the increased number of royalties will not compensate him for the lost profits on the sales relinquished. 
A patent policy which heightens the value of self-production and discriminates against final patentees seems unjustifiable. The patent monopoly has traditionally been viewed as a reward for invention alone, not invention plus subsequent exploitation. ${ }^{35}$ Not only does a policy encouraging exclusive selfproduction so depart from the aims of patent law, it contravenes values inherent in antitrust legislation. ${ }^{36}$ Initially, widespread licensing assures the existence

35. Invention and subsequent disclosure of the patented discovery has long been the primary objective of the patent law. Continental Paper Bag Co. v. Eastern Paper Bag Co., 210 U.S. 405, 424 (1908) ; Grant v. Raymond, 31 U.S. (6 Pet.) 218, 241-42 (1832); Toularn 4; Mitman, Economic Aspects of Inventions and Legal Monopolies, 26 Miss. L.J. 149, 152-54 (1955). The form and source of exploitation has been considered a problem unrclated to the patent grant. For patentees may even suppress the patent for the period of their temporary monopoly with no resultant loss of patent privileges. Special Equipment Co. v. Coe, 324 U.S. 370, 378-79 (1945); Hartford-Empire Co. v. United States, 323 U.S. 386, 433 (1945) ; Crown Die \& Tool Co. v. Nye Tool \& Mach. Works, 261 U.S. 24, 34-35 (1923). For discussion severely criticizing this position, see Special Equipment Co. v. Coe, supra at 380 (dissenting opinion) ; Edwards, Maintaining ComPETITION 238-42 (1949); Castle, Recent Trends in Compulsory Licensing in Case of Nonuse of Patents: A Comparative Analysis, 36 J. Pat. OfF. Soc'y 330 (1954); Feuer, The Patcnt Privilege and the TNEC Proposals, 14 TEMr. L.Q. 180, 190-94 (1940). But see Davis, Putting Patents to Work, 36 J. Pat. Orf. Soc'y 713 (1954). And the constitutional grant authorizing Congress to establish a patent system does not contemplate the source of exploitation: "The Congress shall have power ... to promote the progress of science by securing for limited time to ... inventors the exclusive rights to their respective ... discoveries." U.S. ConsT. art. I, § 8, cl. 8; Brown, The Constitutional Purpose, 31 J. Par. Ofr. Soc'y 643 (1949).

36. The courts have traditionally distinguished the loose-knit combination-union of competitors by agreement without any property link-from the single trader. See, c.g., American Column \& Lumber Co. v. United States, 257 U.S. 377, 418 (1921) (dissenting opinion). If a number of independent firms attempt to accomplish by agreement price control, territorial division, group boycott or resale price maintenance, a Sherman Act violation may very well result. 26 STAT. 209 (1890), 15 U.S.C. $\$ \S 1,2$ (1952); see United States v. Socony-Vacuum Oil Co., 310 U.S. 150 (1940) (price control by producers of over $50 \%$ of the market held illegal); United States v. Trenton Potteries Co., 273 U.S. 392 (1927) (price control by producers of over 82\% of the market held illegal); United States v. Addyston Pipe \& Steel Co., 85 Fed. 271 (6th Cir. 1898), aff'd, 175 U.S. 211 (1899) (territorial division by producers of $60 \%$ of the relevant market held illegal); Fashion Originators' Guild, Inc. v. FTC, 312 U.S. 457 (1941) (group boycott by manufacturers producing $38 \%$ of dresses selling at $\$ 6.75$ and up and $60 \%$ of dresses selling at $\$ 10.95$ and up held illegal). For a detailed discussion of the characteristics and judicial treatment of loose-knit combinations, see Hale, Agreements Among Competitors: Incidental and Reasonable Restraints of Trade, 33 MinN. L. Rev. 331 (1949). However, one firm with an equally large percentage of the market, may create the same conditions which the independent firms were attempting to promote, merely by setting a price, refusing to deal with a particular purchaser or building a retail outlet for its produce. United States v. Aluminum Co., 148 F.2d 416, 427-28 (2d Cir. 1945); Note, 66 Y AIE L.J. 1251, 1252-53 (1957). And, generally, the minimum market power necessary to effect these results is held not violative of the Sherman Act. Id. at 1253 n.6. See also United States v. E. I. Du Pont de Nemours \& Co., 351 U.S. 377 (1956). Only when the firm controls the extremely high percentage of the market necessary to meet the monopolization requirements of $\S 2$ of the Sherman Act, or engages in a conspiracy to monopolize trade, will a violation be found. See United States v. Aluminum Co., supra (monopoly power); United States 
of firms with sufficient facilities, know-how and market penetration to allow competition upon expiration of the patent or to facilitate generalized production in an emergency. ${ }^{37}$ Further, it fosters the recognized policy of aiding small competitors: $:^{38}$ patentees with neither the facilities nor the credit to produce the patented product independently may exploit by licensing. Finally, more perfect allocation of resources results as the inefficient producer is encouraged to allow efficient firms to commercialize the patent rather than to prefer self-production, even at less than optimum volume, to licensing without restrictions. ${ }^{39}$

v. United Shoe Mach. Corp., 110 F. Supp. 295 (D. Mass. 1953) (attempt to gain and keep control of an extremely large portion of an industry). For an analysis tracing the growth of the dichotomy between the loose-knit and close-knit combination, see Note, 66 Y YLE L.J. 1251, 1254-56 (1957).

The cause of such divergent treatment would not appear to be judicial sympathy for the large corporation. In part, it results from a feeling that it would be "unfair" to attack a corporation which has grown large exclusively by legal means: "A single producer may be the survivor of a group of active competitors, merely by virtue of his superior skill, foresight, and industry. In such cases a strong argument can be made that, although the result may expose the public to the evils of monopoly, the act does not mean to condemn the resultant of these very forces which it is its prime object to foster .... The successful competitor, having been urged to compete, must not be turned upon when he wins." United States v. Aluminum Co., supra at 430 . However, the liberal treatment is primarily due to the fear of dissolving these large economic concentrations because of the uncertainty of the effect which dissolution would have upon the economy. See, e.g., Jones, The Problems of Size in Antitrust Thinking: Theories in Search of Facts, 3 U.C.I.A.L. REv. 141 (1956). Finally, while agreements between competitors are generally directed toward anticompetitive goals, advantages of scale may inhere in the large firm. Thus, with enhanced efficiency, a stabilizing effect upon the economy and resources to advance technology, the close-knit combination may be a socially useful institution. See Machlup, The Political Economy of Monopoly c. 3 (1950).

No comparable arguments may be found to favor exclusive self-production by the patentee. No problems as to dissolution and the resulting economic effect exist. And even should efficiency result from concentrated production, the public need derive no benefit from the patentee's monopoly position. Moreover, strong arguments favor widespread licensing. See notes 37-39 infra and accompanying text.

37. Compulsory licensing is often recommended as an antidote to the evils of the patent system. Edwards, Maintaining Conipetition 242-43 (1949). The Attorney General's Committee suggested it as one of the chief remedies for patent abuse. ATr'y GEN. REP. 255-59. A minority even thought that royalty-free compulsory licenses were authorized by the antitrust laws. Ibid. Compulsory licenses were used as corrective measures in United States v. National Lead Co., 332 U.S. 319 (1947) ; Hartford-Empire Co. v. United States, 323 U.S. 386 (1944); United States v. United Shoe Mach. Corp., supra note 36.

38. See United States v. Aluminum Co., 148 F.2d 416, 427 (2d Cir. 1945) ; Loevinger, Antitrust, Economics and Politics, 1 ANTiTrust BuLr. 225 (1955); Comment, 66 YaLE L.J. 69 (1956).

39. An inefficient patentee who can fully exploit by licensing would not be tempted to invest his resources in a field for which he is unsuited. The production would be handled by the most efficient producers, hence effected at the lowest possible cost and the least expenditure of resources. See BAIN, PrICE Theory $152-59$ (1952); note 40 infra.

If encouraged to prefer self-production, a final-good patentee with insufficient capacity to produce at the optimum level would supply consumers with less of his product at a 
Any agreement resulting in price restraint should, of course, be viewed with suspicion. Like price control in the broader commercial marketplace, patent-licensing restrictions negate price competition and its attendant benefits. ${ }^{40}$ Therefore, a general policy voiding price or quantity licensing limitations could effectively advance the values of antitrust legislation. But the total concept of the patent monopoly impinges upon generalized antitrust philosophy. ${ }^{41}$ To encourage invention, Congress has specifically established a temporary monopoly protecting the patented disclosure. ${ }^{42}$ Within that context, licensing

higher price than that which would maximize his returns. This follows from the necessary relationship between price and output. See note 22 supra. With intermediate patents, insufficient production may not bring higher prices since maximum price is set by the price of the replaced product or process. However, the economy suffers to the extent that less efficient products or methods are used instead of the patented good. The object of any economic system is to produce a given output with the lowest possible outlay of resources. Bain, Price Theory 152-59 (1952) ; Peterson, Economics 30-34 (1949).

40. United States v. Line Material Co., 333 U.S. 287, 317-20 (1948) (concurring opinion); ATT'Y GEN. REP. 235-36 (dissent of Louis B. Schwartz).

Price is the directing force in a system of free enterprise for allocating resources and determining distributive shares of the total product. Theoretically, if prices are permitted to find their natural level, scarce resources will be optimally allocated-consumers will receive those goods that will maximize satisfactions, produced by the most efficient means. If these goals are to be reached or approximated, prices must be free to move in response to market forces and not be impeded by restrictions in the form of collusive agreements. Bain, Price Theory 152-72 (1952).

Simultaneously, price competition protects the consumer from extortion by sellers charging prices significantly above costs. Each producer is forced to keep price low and quality high for fear of losing business to others who will undercut him. Invention is stimulated by the fear of a competitor lowering his costs, and subsequently his selling price. Inefficient producers unable to compete pricewise with their lower cost rivals are eliminated. Wircox, Conpetition and Monopoly in AMERICAN INdustry (TNEC Monograph No. 21, 1940). See also Stocking \& Watkins, Monopoly and Free EnTERprise c. 1 (1951).

But price competition is not without drawbacks. Unruly markets may result in cutthroat competition and predatory price policies. Moreover, in periods of economic recession, highly flexible prices may accentuate the decline if businessmen cut prices in efforts to capture part of the dwindling demand. Finally, it has been argued that some abatement of price competition, leading to the possibility of monopoly profits, is necessary to induce entrepreneurs to take the great risks involved in developing and marketing large-scale innovations in product or technique. Schumpeter, Capitalism, Socialism AND DeMocracy 81-107 (3d ed. 1950).

41. See Edwards, Matntaining Coarpetrtion 216-35 (1949) (patent may be used to increase the concentration of power and further monopolistic abuses); Levine, The Shrunken Patent Donain in the Expanded Anti-trust Unizerse, 34 J. PAT. OFF. Soc'y 436 (1952) (any patent-induced restriction of competition will be held an antitrust violation); Petro, Patents: Judicial Developments and Legislative Proposals, 12 U. CEI. L. Rev. 80, 352 (1944) (patents are the source of monopolistic abuses). Contra, Schramm, Relationship of the Patent Act of 1952 to the Antitrust Lawes, 23 GEo. WASH. L. Rev. 36 (1954) (no conflict between ownership of a patent and the antitrust laws); Diggins, The PatentAntitrust Problem, 53 Mich. L. Rev. 1093 (1955) (each has a well-defined scope).

42. 35 U.S.C. $\$ 1$ 1-293 (1952). Patents are specifically provided for in the Constitution. See note 35 supro. 
restrictions do foster competitive goals by promoting widespread licensing. Whether or not such limitations should be a part of the patent reward is a problem long debated and unresolved. ${ }^{43}$ Congress has in part legislated an answer. It has expressly authorized territorial limitations and impliedly condoned the long-standing practice of price restrictions. ${ }^{44}$ Narrow revision of this policy through such mechanisms as the single-licensee doctrine is unsatisfactory. Broad revision, requiring delicate adjustment of the patent law grant and antitrust rejection of monopoly power, might better lie with the Congress than the courts.

43. Numerous unsuccessful attempts have been made to amend the patent laws to prohibit price fixing in licenses. United States v. Line Material Co., 333 U.S. 287, 303 n.18 (1948); dissenting opinion of Burton, J., id. at 362-63.

44. See Lutz, Are the Courts Carrying Out Constitutional Public Policy on Patents?, 34 J. Pat. OfF. Soc'y 766 (1952); Thomas, supra note 5. Contra, Edwards, MaintainIng Competition 244-48 (1949); Meyers \& Lewis, The Patent "Franchise" and the Antitrust Lazes, 30 GEo. L.J. 117, 260, $267-75$ (1942); Watkins \& Stocking, Patent Monopolies and Free Enterprise, 3 VAND. L. REv. 729 (1950). 